\title{
THE EFFECT OF PROBLEM BASED LEARNING MODEL ON STUDENT'S LEARNG OUTCOMES IN STATIC FLUID TOPIC OF CLASS X SMA NEGERI 3 MEDAN ACADEMIC YEAR $2013 / 2014$
}

\author{
Evi Kamelia Simanjuntak and Motlan \\ evisimanjuntak1@gmail.com \\ Jurusan Fisika FMIPA Universitas Negeri Medan \\ Jalan Willem Iskandar Pasar V Medan, 20221
}

\begin{abstract}
The aim of this research is to knowthe effect of the problem based learning model on student's learning outcomes in static fluids topic.The research method is quasi experiment. The populations are all of students in class X MIA semester II SMA N. 3 Medan, that consist of 14 classes. The sample of this research was taken by cluster random sampling technique, class $\mathrm{X}$ MIA-4was experimental class used problem based learning model that consist of 38 students, and class X MIA-5 as control class used conventional learning, consist 40 students. Instruments that used in this research were multiple choose test instrument and psychomotor and affective observation sheet. The data obtained from the test was analyzed by statistical analysis ttest. Based on observation result by using affective and psychomotor observation sheet of studentsshown that there was significant increasing on experimentalclass.So,it can be concluded that the student'slearning outcomes using problem based learning model greater than conventional learning of static fluid topic of class X SMA N.3 Medan academic year 2013/2014.
\end{abstract}

Keywords : Problem Based Learning Model, Student'sLearning Outcomes

\section{INTRODUCTION}

Learning process occurs through many ways and takes place all the time toward a behavior changing in learners. The changing are in the form of knowledge, understanding, skills, and habits that acquired by the learners. The main activities in teaching and learning are the emphasis on engaging students in learning.

One of the subjects that taught in school, especially in high school is physics. Physics is the science that studies about natural phenomenon. Therefore, physics is one of the lessons that quite interesting because it relates directly to natural phenomena and knowledge can be applied in daily life.

But in fact physics is one boringlesson that has the lowest score. This is caused by the large number of students who do not like physics and they think physics is a difficult subject to understand, it's caused by, when learning, students more emphasis to memorize the formula, withoutemphasizingthe understandingandapplication ofconceptsin their daily lives.This 
fact is in accordance with the results of observations conducted by researchers in SMANegeri 3 Medan.

Researcher observe the student's interest in physics subject bygiving the question naire instrument to the students class $\mathrm{X}$ which have 40 respondents, the observati on results indicate that: $44.4 \%$ of students stated that learning physics in classroom is difficult to understand and boring, $33.3 \%$ stated that learning physics ordinary, and $22.2 \%$ stated that teaching physics inclass is interesting and challenging. Based on the question naire also found that before the physics materiall taught in class, $10 \%$ said students are studying at home and notes what they don't understood, 25\% said sometimes learn at home, $35 \%$ just look at the topic title, and 30\% did not learn and open physics book (nothing their preparation). Through a question naire instrument is also known that almost all respondents said that the usual way of teaching by physics teacher is lecturing, note and give the question to do. From the observation result above, researcher conclude that student in SMA Negeri 3 Medan isn't interest to learn physics and this will be influenced the student outcome in learning physics.

Researchers also interviewed six physics teachersof SMA Negeri 3 Medan. They said that when students are taught the theory with the direct instruction in class the students' interest towards physics lessons are less. Meanwhile, when the students were taken to the laboratory for experiment it takes a lot time, and the laboratory facility is also incomplete, so the learning model used is a direct learning with lectures, notes, do the problems, and sometimes making demonstration. Minimum competency standard in the school for physics subjects is 75 . However, $52.5 \%$ of students do not achieve the minimum competency standard at the end of semester exams.

Therefore, to overcome the low physics student learning outcomes, it is necessary to use or perform a variety method, for example usinga method of effective teaching and learningin accordance with the objectives set in the curriculum. Problem Based Learning Model is chosen because in learning process, the student faced to the really daily lives problem. So, student able to solve the problem and get the knowledge and important concept by their selves (Kharida, dkk, 2009). Problem based learning aims improve students' ability to work in a team, showing their coordinated abilities to access information and turn it into viable knowledge (Bilgin, et all, 2009). Problem based learning is an effective method for improving students' problem-solving skills. Students will make strong connections between concepts when they learnfacts and skills by actively working with information rather than by passively receiving information (Valerie Ross, 2001).

From previous research, Nurjannah Sitanggang(2012) in MAN 1 Medan in the subject matter of rigid body equilibrium using $\mathrm{PBL}$, obtainedan increase value ofpre-test to post-test in the experimental classis 44.29 and 37.68 at controls class. Avolen Berly Siahaan (2013) also conducted a research in SMP N.1 Tebing Tinggi using PBL in subject matter is light in class VIII, 
the increase ofthe average pretest to posttest value in experiment class is 46.04 and in control class is 12.9 . And the research also conducted by Janiar Satrini Gultom (2013) in SMA N. 3 Medan for topic static fluid using PBL that conducted in the second class, had the increase of value pretest to posttest in experiment class is 38,95 and in control class is 35.744 . From these studies it can be seen that, there is the effect between problem based learning modeland student learning outcomes. Based on the explanation above, the researcher want to do a research with the title "The Effect of Problem Based Learning Model on Student's Learning Outcomes in Static Fluid Topic of Class X SMA Negeri 3 Medan Academic Year 2013/2014".

\section{Research Method}

This research was conductedin SMA Negeri 3 Medanat class $\mathrm{X}$ on April academic year 2013/2014. Population of this research is all students in class $\mathrm{X}$ SMA Negeri 3 Medan academic year $2013 / 2014$ that consist of 14 classes, and each classes consist of $38-40$ students. The sample that would be taken is choosen by cluster random sampling. The sample is divided into two classes consisting of one class as experimental class and the other class as control class.

This research is involves two different treatments for the experimental class and the control class, where the two classes are treated differently. The experimental class treated with guided inquiry learning model and the control class treated with conventional learning.
To determine the student's understanding of the concept is done by giving test on both classes before and after treatment, which are calledpretest and posttest. The design of the research is as follows:

Table 1 Design of Research

\begin{tabular}{|lccc|}
\hline \multicolumn{1}{|c}{ Class } & Pre & Treatment & $\begin{array}{c}\text { Post } \\
\text { test }\end{array}$ \\
Experiment & $\mathrm{X}_{1}$ & $\mathrm{P}$ & $\mathrm{X}_{2}$ \\
Control & $\mathrm{X}_{1}$ & $\mathrm{Q}$ & $\mathrm{X}_{2}$ \\
\hline
\end{tabular}

Description:

$$
\begin{aligned}
\mathrm{X}_{1}= & \text { Pretest } \\
\mathrm{X}_{2}= & \text { Posttest } \\
\mathrm{P}= & \text { Learning using problem } \\
& \text { learning model } \\
\mathrm{Q}= & \text { Learning using conventional } \\
& \text { learning } \\
& \text { The selection of data is }
\end{aligned}
$$
carried out to observe whether the samples come from normal distribution population or not. The test used is Liliefors test and Homogeneity test, to know the homogenity of both samples used formula as follows (Sudjana, 2005) :

$$
F_{\text {count }}=\frac{S_{1}{ }^{2}}{S_{2}{ }^{2}}
$$

Description:

$S_{1}^{2}=$ Biggest Variance Data

$S_{2}{ }^{2}=$ Smallest Variance Data

The test criteria are received

Ho : the data come from a homogeneous population if $\mathrm{F}$ count $<\mathrm{F}$ table, where the $\mathrm{F}$ table obtained from the distribution list $\mathrm{F}$ with $\alpha=0.05$. Here $\alpha$ is a real level for testing.

Hypothesis test use t-test with formula (Sudjana, 2005):

$$
t=\frac{\bar{x}_{1}-\bar{x}_{2}}{S \sqrt{\frac{1}{n_{1}}+\frac{1}{n_{2}}}}
$$


$\mathrm{S}$ is combination of standard deviation can be calculated with formula:

$$
S^{2}=\frac{\left(n_{1}-1\right) S_{1}^{2}+\left(n_{2}-1\right) S_{2}^{2}}{n_{1}+n_{2}-2}
$$

Where:

$\bar{x}_{1}=$ Average value in experimental class.

$\bar{x}_{2}=$ Average value in control class.

$n_{1}=$ Total of sample in experimental class.

$n_{2}=$ Total of sample in control class. $S^{2}=$ Variance

$S_{1}^{2}=$ Variance in experimental class

$S_{2}{ }^{2}=$ Variance in control class

$\mathrm{t}=\mathrm{t}$ distribution

Testing Criteria : $\mathrm{H}_{\mathrm{o}}$ accept if $\mathrm{t}_{\text {count }}<\mathrm{t}_{(1-\alpha)}$ where $\mathrm{t}_{(1-\alpha)}-\alpha$ get from distribution table $t$ with independent degree $(\mathrm{dk})=\mathrm{n}_{1}+\mathrm{n}_{2}-2$ and the probability $(1-\alpha)$ with $\alpha=$ 0,05 for another value of $t \mathrm{H}_{\mathrm{o}}$ not accept, so Problem Based Learning Model greater than the student's learning outcomes using conventional learning.

\section{Research Results}

The result of research show that the students' learning outcomes instatic fluidstopic that used problem based learning model is greater than conventional learning in class X SMA Negeri 3 Medan.The result obtained that the posttest average value in experimental class was78.94with deviation standard was 10.68, while the posttest average value in control class is69 with deviation standard was 14.04 .

Students' learning outcomes in affective domain of experimental class using problem based learning model at meeting I was 72.45 , meeting II was 85.08 , and meeting III was 85.26 , so the average valueof students' affective in experimental class was 80.93. While, students' learning outcomes in affective domain of control class using conventional learning at meeting I was 66.5 , meeting II was 71.67 , and meeting III was 73.16 , so the average value of students' affective in control class was 70.44. Both experimental and control class were in good category butaffective of student in experimental class has significant increasing because the learning process using the Problem BasedLearning Model which is student center learning, so the student more active in the learning process. As general Problem BasedLearning Model make student become responsible with their behavior. For control class the students have low affective because conventional learning make teacher as center of learning.

Students' learning outcomes in psychomotor domain of experimental class using problem based learning model at meeting I was 71.05 , meeting II was 78.07 , and meeting III was 84.21 , so the average valueof students' affective in experimental class was 77.78. While, students' learning outcomes in psychomotor domain of control class using conventional learning at meeting I was 43.33 , meeting II was 49.44, and meeting III was 50.83, so the average value of students' affective in control class was 47.87. Experimental was in good category while in control class is in poor category, student's learning outcomes bigger in the experimental class because student is more active and students are directly involved in the learning activity (students center learning). Because the model is designed to bring students 
directly into scientific process into small periods of time and the training has resulted in an increased understanding of science, more creative thinking, and skills for obtaining and analyzing information as students establish facts, build concepts, and then generate and test explanations or theories when doing the experiment. The psychomotor of student in control class have lower value, because they do not do the experiment, and just doing the exercise given by researcher. So the psychomotor of student in control class become low.

The student's learning outcome Cognitive, Affective, and Psychomotor domain onstatic fluidstopic using problem based learning model is greater than conventional learning in class $\mathrm{X}$ SMA Negeri 3 Medan.

Theresult of cognitive domain show edac quisition value of the average pretest in the experimental classis 27.19 with a deviation standard is 12.33 and the average post test value is 78.94 with a deviation standard is 10.68 . While the values obtained in the control class average pretest is 24.5 with a deviation standard is 11.33 and the average post test value is 69 with a deviation standard is 14.05. From the data, average post test value in experimental class is greater than control class. The increasing of posttest value is caused by the treatment given to the students. In experimental class given treatment using problem based learning model and control class given the treatment using conventional learning.

The observation result in psychomotor domain showed activeness of students during the learning greatly affects the value of learning outcomes. The activity of student can be seen more specific from doing worksheet in the experimental class and in control class, the activity of students can be seen when the researcher doing the teaching activity and giving problems.When students were activein the learning activities then thelearning outcomes become higher. There is different activity of students' in experimental class and control class. The average value of students' activity in experimental class is higher than control class. It also caused the average value of posttest value in experimental class is greater than control class.

Problem based learning model is a better than conventional learning. It is better than conventional learning because in problem based learning model student actively participate in the learning process and understand how that they learn by doing experiment. During the implementation of the research showed that problem based learning model bring students directly into scientific process into small periods of time and the training has resulted in an increased understanding of science, more creative thinking, and skills for obtaining and analyzing information as students establish facts, build concepts, and then generate and test explanations or theories. Thus, the students are active learners involved in exploration, questioning, problem solving, inductive reasoning, invention, labeling, and discovery, while in the control class that use direct instruction learning model students just sit and listen to the 
teacher's explanation without trying to solve problem.

This evident from several researchers who have conducted research about problem based learning model, including; Janiar Satrini Gultom (20113) that researched students in SMA N.3 Medan, Nurjannah Sitanggang (2012) in MAN 1 Medan, Avolen Berly Siahaan (2013) in SMP N.1 Tebing Tinggi, Mariana Lumbantobing (2014) in SMA N.11 Medan. These researchers shows that by using problem based learning model in learning can improve student's learning outcomes, student's activities and enhance student's interest that was activeness in following the learning process.

Although the using of problem based learning model can improve the students' learning outcomes, but as long as teaching and learning process run still there are students who less interested in concept learning. Because they have been accustomed to working on the problems when study with physics calculations and also the condition of class was difficult to controll because discussion chance in teaching and learning process giving chance for some students making noise so bothered other group discussion, and also time allocation that limited making the group discussion is not maximal, and the group discussion result can't present for all group in front of class.

\section{Conclusion}

Based on the research result, data analysis, and discussion can be concluded that:

(1) The average value of students' learning outcomes using problem based learning model is greater than the students' learning outcomes using conventional learning. (2) Students' activity as long as using problem based learning model increased, from the first meeting up to the third meeting. The category of students' activity is good. And students' affective as long as using guided inquiry learning model also increased, from the first meeting up to the third meeting. The category of students' affective is good. (3) Based on theresults of data analysis, the processing of hypothesis test using $t$-test get that $t_{\text {count }}>t_{\text {table, }}$, so it can be stated that the students' learning outcome instatic fluids topic using problem based learning model is greater than conventional learning in static fluid topic of class X SMA Negeri 3 Medan.

\section{Suggestion}

Based on the research result and discussion before, researcher give suggestions as follow: Due to the weakness of researcher on teaching and learning activities as well as descriptors of activity in this study is suggested to pay more attention to the implementation stages according to the model of problem based learning activities and develop a better descriptor.

\section{Refferences}

Bilgin, I., Senocak, E., Sozbilir, M., (2009) The Effects of Problem BasedLearning Instruction on University Students' Performance of Conceptual and Quantitative Problems in Gas Concepts, Eurasia Journal of Mathematics, Science \& Technology Education 5: 153164 
Gultom, J. S. (2013), The Effect Of Problem Based Learning Outcomes INStaticFluid Topic For ClassXI AtSMA Negeri 3 Medan Academic Year 2012/2013., Skripsi, FMIPA, Unimed, Medan.

Hewitt, P., G., (2006), Conceptual Physics, Tenth Edition, Pearson AddisonWesley, San Fransisco

Joyce, B., and Weil, M., (1967), Models of Teaching, Prentice/Hall International, Inc, New Jersey.

Kanginan, M., (2013), Fisika untuk SMA/MA Kelas X, Penerbit Erlangga, Jakarta.

Kharida, L. A., Rusilowati, A., Pratiknyo, K., (2009), Penerapam Model Pembelajaran Berbasis Masalah Untuk Peningkatan Hasil Belajar Siswa Pada Pokok Bahasan Elastisitas
Bahan, Jurnal Pendidikan Fisika Indonesia 5: 83-89

Ross, V., (2001), Problem-Based Learning, Stanford University Newsletter onTeaching, CTL Journal Teaching and Learning 11: 1

Siahaan, A.B. (2013), The Effect Of Problem Based Learning Model On Student's Achievement At Light Topic In 8 th Grade SMP Negeri 1 Tebing Tinggi A.Y 2012/2013., Skripsi, FMIPA, Unimed, Medan.

Sitanggang, N. (2012), Pengaruh Model Pembelajaran Berbasis Masalah Terhadap Hasil Belajar Siswa Pada Materi Pokok Kesetimbangan Benda Tegar Di Kelas XI MAN 1 Medan., Skripsi, FMIPA, Unimed, Medan.

Sudjana, (2005), Metoda Statistika, Penerbit Tarsito, Bandung. 